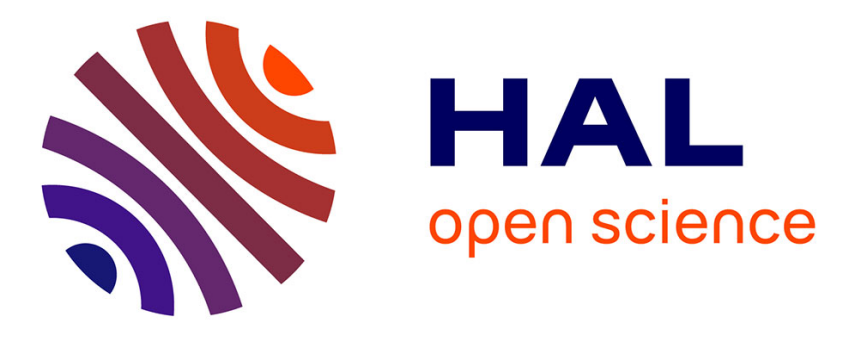

\title{
Oxygen isotope fractionation between human phosphate and water revisited
}

\author{
Valérie Daux, Christophe Lécuyer, Marie-Anne Héran, Romain Amiot, \\ Laurent Simon, François Fourel, François Martineau, Niels Lynnerup, Hervé \\ Reychler, Gilles Escarguel
}

\section{To cite this version:}

Valérie Daux, Christophe Lécuyer, Marie-Anne Héran, Romain Amiot, Laurent Simon, et al.. Oxygen isotope fractionation between human phosphate and water revisited. Journal of Human Evolution, 2008, 55, pp.1138-1147. 10.1016/j.jhevol.2008.06.006 . halsde-00341152

\section{HAL Id: halsde-00341152 https://hal.science/halsde-00341152}

Submitted on 4 Dec 2019

HAL is a multi-disciplinary open access archive for the deposit and dissemination of scientific research documents, whether they are published or not. The documents may come from teaching and research institutions in France or abroad, or from public or private research centers.
L'archive ouverte pluridisciplinaire HAL, est destinée au dépôt et à la diffusion de documents scientifiques de niveau recherche, publiés ou non, émanant des établissements d'enseignement et de recherche français ou étrangers, des laboratoires publics ou privés. 


\title{
Oxygen isotope fractionation between human phosphate and water revisited
}

\author{
Valérie Daux ${ }^{\mathrm{a}, *}$, Christophe Lécuyer ${ }^{\mathrm{b}}$, Marie-Anne Héran ${ }^{\mathrm{b}}$, Romain Amiot ${ }^{\mathrm{b}}$, Laurent Simon ${ }^{\mathrm{c}}$, \\ François Fourel ${ }^{\mathrm{b}}$, François Martineau ${ }^{\mathrm{b}}$, Niels Lynnerup ${ }^{\mathrm{d}}$, Hervé Reychler ${ }^{\mathrm{e}}$, Gilles Escarguel ${ }^{\mathrm{b}}$ \\ ${ }^{a}$ Laboratoire des Sciences du Climat et de l'Environnement/IPSL, UMR CEA/CNRS 1572, L'Orme des Merisiers, Bât. 701, CEA Saclay, 91191 Gif/Yvette Cedex, France \\ b Laboratoire CNRS UMR 5125 “Paléoenvironnements E' Paléobiosphère," Université Claude Bernard Lyon 1, Campus de la Doua, F-69622 Villeurbanne, France \\ 'Laboratoire CNRS UMR 5023 "Ecologie des hydrosystèmes fluviaux," Université Claude Bernard Lyon 1, Campus de la Doua, F-69622 Villeurbanne, France \\ ${ }^{\mathrm{d}}$ Laboratory of Biological Anthropology, The Panum Institute, Blegdamsvej 3, DK-2200 Copenhagen, Denmark \\ ${ }^{\mathrm{e}}$ Service de Stomatologie et Chirurgie maxillo-faciale, Université Catholique de Louvain, Cliniques universitaires Saint-Luc, av. Hippocrate 10, 1200 Bruxelles, Belgium
}

The oxygen isotope composition of human phosphatic tissues $\left(\delta^{18} \mathrm{O}_{\mathrm{P}}\right)$ has great potential for reconstructing climate and population migration, but this technique has not been applied to early human evolution. To facilitate this application we analyzed $\delta^{18} \mathrm{O}_{\mathrm{p}}$ values of modern human teeth collected at 12 sites located at latitudes ranging from $4^{\circ} \mathrm{N}$ to $70^{\circ} \mathrm{N}$ together with the corresponding oxygen composition of tap waters $\left(\delta^{18} \mathrm{O}_{\mathrm{W}}\right)$ from these areas. In addition, the $\delta^{18} \mathrm{O}$ of some raw and boiled foods were determined and simple mass balance calculations were performed to investigate the impact of solid food consumption on the oxygen isotope composition of the total ingested water (drinking water + solid food water). The results, along with those from three, smaller published data sets, can be considered as random estimates of a unique $\delta^{18} \mathrm{O}_{\mathrm{W}} / \delta^{18} \mathrm{O}_{\mathrm{P}}$ linear relationship: $\delta^{18} \mathrm{O}_{\mathrm{W}}=1.54( \pm 0.09) \times \delta^{18} \mathrm{O}_{\mathrm{p}}-33.72( \pm 1.51) \quad\left(\mathrm{R}^{2}=0.87\right.$ : $\mathrm{p}$ $\left.\left[\mathrm{H}_{0}: \mathrm{R}^{2}=0\right]=2 \times 10^{-19}\right)$. The $\delta^{18} \mathrm{O}$ of cooked food is higher than that of the drinking water. As a consequence, in a modern diet the $\delta^{18} \mathrm{O}$ of ingested water is +1.05 to $1.2 \%$ higher than that of drinking water in the area. In meat-dominated and cereal-free diets, which may have been the diets of some of our early ancestors, the shift is a little higher and the application of the regression equation would slightly overestimate $\delta^{18} \mathrm{O}_{\mathrm{W}}$ in these cases.

\section{Introduction}

In recent years, the study of prehistoric cultures has benefited from the use of stable isotope analyses. The majority of these studies have focused on the Holocene portion of human evolution, however, isotopic investigations may provide critical information about our earliest ancestors' diet and ecological setting (climate and environment). Such information plays a critical role in scenarios that seek to explain the evolution of early humans. For example, stable nitrogen and carbon isotope analyses of bone collagen (e.g., Ambrose and De Niro, 1986; Bocherens et al., 1991; Fizet et al., 1995; Richards et al., 2005) and carbon isotope analysis of bone and tooth carbonate (Lee-Thorp et al., 1994; Van der Merwe et al., 2003; Sponheimer et al., 2005) have been used to reconstruct the diet of some of our pre-Holocene ancestors. However, oxygen isotope compositions of human phosphatic tissues, which can be used to reconstruct climatic conditions (e.g., Fricke et al., 1995; Müller et al., 2003; Daux et al., 2005; Evans et al., 2006), identify foreigners in a population, assess the mobility of human groups

\footnotetext{
* Corresponding author.

E-mail addresses: valerie.daux@lsce.ipsl.fr (V. Daux), clecuyer@univ-lyon1.fr (C. Lécuyer).
}

(e.g., White et al., 2000; Dupras and Schwarcz, 2001; White et al., 2007), or reconstruct infant feeding behavior (e.g., Wright and Schwarcz, 1998), have not been applied, to our knowledge, to issues of early human evolution.

The ratio of oxygen isotopes in mammalian flesh, bones, and teeth reflects the origin of water imbibed as a liquid and ingested from food. The water contained in food has a complicated relationship with meteoric water and can be significantly enriched in ${ }^{18} \mathrm{O}$ compared to meteoric water. The relative contribution of water entering the body as a liquid and from food varies from one species to another. Animals with low water turnover are expected to derive more water from isotopically-enriched food sources and less from drinking water than are those with high water turnover (Kohn et al., 1996). For the vast majority of terrestrial vertebrates, water turnover scales to body mass (e.g., Altman and Dittmer, 1968; Eberhardt, 1969). Therefore, the $\delta^{18} \mathrm{O}$ of the tissues of large animals should be less affected by their solid food consumption than is the $\delta^{18} \mathrm{O}$ of smaller animals. However, the influence of diet on the isotopic composition of the tissues may not depend only on water turnover but also on the proportion of water taken up as water contained in food. By way of example, larger herbivores consume plants that are highly hydrated ( 80 to $95 \%$ water by weight) and may contribute up to $50 \%$ of the total ingested water (from statistics 
of Agriculture and Agri-food Canada). As a result, large herbivores obtain a large proportion (up to 50\% for wild herbivores; Kohn et al., 1996) of their oxygen from plants that are isotopically enriched. In contrast, the influence of food on tissue $\delta^{18} \mathrm{O}$ is insignificant in animals that are fed dry food (Luz et al., 1984).

Humans are medium size mammals with moderate water turnover. As we are mainly omnivores, we ingest less water from food sources than do herbivores. Therefore, the $\delta^{18} \mathrm{O}$ ingested by humans is strongly imprinted by the composition of our drinking water, which is strongly linked to environmental water (Longinelli, 1984; Luz et al., 1984; Levinson et al., 1987). Although there is a linear relationship between the oxygen isotope composition of human phosphate and the composition of meteoric water, the three previously-published fractionation equations differ in both their slope and intercept values (Longinelli, 1984; Luz et al., 1984; Levinson et al., 1987). This variation may result from the use of different analytical techniques among studies, small datasets that sample a restricted range of variation, or differences in the timing and duration of crown mineralization from one individual to another. Additionally, although not thought to be a big influence, diet may influence the oxygen isotopic composition of human tissues and contribute to the variation among studies. Although thought to be small, the effect of specific diets on $\delta^{18} \mathrm{O}_{\mathrm{p}}$ is unknown. One can question the impact on $\delta^{18} \mathrm{O}_{\mathrm{p}}$ of a vegetarian or a meatbased diet, the effect of cereal consumption, or the consequence of cooking food. If specific diets prove to have a sizable influence on $\delta^{18} \mathrm{O}_{\mathrm{P}}$, they would need to be considered when reconstructing paleoclimate from the isotopic signature of phosphatic tissues. Conversely, the $\delta^{18} \mathrm{O}_{\mathrm{p}}$ of individuals of known isotopic context $\left(\delta^{18} \mathrm{O}_{\mathrm{W}}\right)$ can provide information on their dietary practices.

In this study, we refine our knowledge of the oxygen isotope fractionation between water and phosphate in human tooth enamel. We provide a new set of oxygen isotope data for teeth of recent humans from $4^{\circ} \mathrm{N}$ to $70^{\circ} \mathrm{N}$. We compare regressions between $\delta^{18} \mathrm{O}_{\mathrm{P}}$ and the $\delta^{18} \mathrm{O}_{\mathrm{W}}$ of their likely drinking water and of meteoric water. We test whether the differences among the previously published datasets (Longinelli, 1984; Luz et al., 1984; Levinson et al., 1987; this study) are statistically significant. We then investigate the effect of diet on $\delta^{18} \mathrm{O}_{\mathrm{P}}$ by measuring the oxygen isotope compositions of water from raw and cooked vegetables, fish, and meat by modeling the impact of variable proportions of these constituents on $\delta^{18} \mathrm{O}_{\mathrm{P}}$.

\section{Materials and methods}

\section{Tooth enamel samples}

We analyzed the oxygen isotopic ratios of 38 molars (36 M1 and M2; 2 M3) from modern or historical (18th century Inuit) individuals from 12 geographic areas that range from about $4^{\circ} \mathrm{N}$ (Cameroon) to $70^{\circ} \mathrm{N}$ (Greenland; Fig. 1). Only one tooth was sampled per individual. In the case of living individuals, informed consent was given by the patients whose teeth were analyzed. Both maxillary and mandibular molars were sampled. Teeth of living individuals were extracted because of periodontal disease or for prosthodontic reasons. Teeth were selected that met the following criteria: 1) the person, according to their own statement, had lived all their childhood in the same place and had drunk local water during this time; and 2) the molar exhibited no evidence of decay.

Once obtained, teeth were crushed and enamel was sorted by handpicking under a microscope. The fragments were cleaned with $15 \%$ hydrogen peroxide for half an hour in an ultrasonic bath and dried in an oven before being crushed to powder in an agate mortar.

Most studies dedicated to the oxygen isotope composition of apatite start by isolating $\mathrm{PO}_{4}^{3-}$ using acid dissolution and anionexchange resin. The protocol used here is derived from the original method published by Crowson et al. (1991) and slightly modified by
Lécuyer et al. (1993). After dissolution of 15 to $30 \mathrm{mg}$ of powdered tooth enamel in $2 \mathrm{M} \mathrm{HF}$ at $25^{\circ} \mathrm{C}$ for 24 hours, the $\mathrm{CaF}_{2}$ that precipitates is separated from the solution that includes the phosphate by centrifugation. The $\mathrm{CaF}_{2}$ precipitate is rinsed three times using double deionized water (DDW) and the rinse water is added to the solution that is neutralized with a $2 \mathrm{M} \mathrm{KOH}$ solution. Cleaned Amberjet ${ }^{\mathrm{TM}}$ resin $(2 \mathrm{ml})$ is added to the neutralized solution in polypropylene tubes. The tubes are placed on a shaker table for 12 hours to promote the ion exchange process. Excess solution is discarded and the resin is washed five times with DDW to remove the traces of ionic contaminants. To elute the phosphate ions quantitatively from the resin, $25-30 \mathrm{ml}$ of $0.5 \mathrm{M} \mathrm{NH}_{4} \mathrm{NO}_{3}$ is added to bring the $\mathrm{pH}$ of the solution to $7.5-8.5$, and the tubes are gently shaken for about 5 hours. Silver phosphate is precipitated from the eluted solution following the method of Firshing (1961). The solution is placed in a $250 \mathrm{ml}$ Erlenmeyer flask and about $1 \mathrm{ml}$ of concentrated $\mathrm{NH}_{4} \mathrm{OH}$ is added to raise the $\mathrm{pH}$ to 9-10. Fifteen $\mathrm{ml}$ of ammoniacal $\mathrm{AgNO}_{3}$ solution is added to the flask. Upon heating this solution to $70^{\circ} \mathrm{C}$ in a thermostatic bath, millimeter-size yellowish crystals of $\mathrm{Ag}_{3} \mathrm{PO}_{4}$ are quantitatively precipitated. The crystals of silver phosphate are collected on a Millipore filter, washed three times with DDW, and air dried at $50{ }^{\circ} \mathrm{C}$.

The ${ }^{18} \mathrm{O} /{ }^{16} \mathrm{O}$ ratios are measured after reaction of silver phosphate with graphite to form $\mathrm{CO}_{2}$ (O'Neil et al., 1994; Lécuyer et al., 1998). $\mathrm{Ag}_{3} \mathrm{PO}_{4}$ samples are mixed with pure graphite powder with precise proportions of $0.5 \mathrm{mg}$ of $\mathrm{C}$ to $8 \mathrm{mg}$ of $\mathrm{Ag}_{3} \mathrm{PO}_{4}$. They are weighed into tin reaction capsules, loaded into quartz tubes, and degassed for 30 minutes at $80^{\circ} \mathrm{C}$ in vacuum. The samples are then heated at $1100{ }^{\circ} \mathrm{C}$ for 1 minute to promote the redox reaction. $\mathrm{CO}_{2}$ samples are analyzed at the University of Lyon with a GV IsoPrime ${ }^{\mathrm{TM}}$ or a GV PRISM II stable isotope ratio mass spectrometer using dual inlet systems with automated cold fingers. Isotopic compositions are quoted in the standard $\delta$ notation relative to Standard Mean Ocean Water (SMOW). The reproducibility of measurements carried out on tooth enamel samples is better than $0.2 \%(1 \sigma)$. Silver phosphate precipitated from standard NBS120c (natural Miocene phosphorite from Florida) was repeatedly analyzed $\left(\delta^{18} \mathrm{O}=21.73 \pm 0.20 ; n=20\right)$ along with the silver phosphate samples derived from the human tooth collection. Calibration of the "graphite method" has been made with oxygen isotope measurements using fluorination. As this technique ensures a total conversion of apatite oxygen to carbon dioxide, any bias resulting from the so called "scale compression factor" (Vennemann et al., 2002) has been corrected by using two standards of distinct oxygen isotope composition. For NBS120c, we obtained a comparable mean $\delta^{18} \mathrm{O}$ value of $21.70 \pm 0.14 \%(n=21)$. To bracket the isotopic range documented in this study, we analyzed the "Durango apatite" which gives a mean $\delta^{18} \mathrm{O}$ value of $+9.45 \%(n=3)$ by offline pyrolysis against a value of $+9.6 \%$ obtained by fluorination using $\mathrm{BrF}_{5}$ reagent (C. France-Lanord, pers. comm.). It must be taken into account, however, that former studies (Longinelli, 1984; Luz et al., 1984; Levinson et al., 1987) used both $\mathrm{BiPO}_{4}$ chemistry and fluorination protocols for isolation of phosphate and extraction of its oxygen. The robustness of the oxygen isotope measurement by various methods has been reported by Lécuyer et al. (1996) who used the two kinds of data to generate an oxygen isotope fractionation equation for lingulids, with the fair and appreciated contribution of Dr. A. Longinelli.

\section{Tap and meteoric waters}

At 11 of the geographic locations from which enamel sampling was undertaken, samples of tap water were collected for oxygen isotope analysis. Oxygen isotope compositions were determined using water-carbon dioxide equilibration methods (Epstein and Mayeda, 1953; O'Neil et al., 1975). Aliquots of $3 \mathrm{ml}$ of water were equilibrated with $30 \mu$ moles of $\mathrm{CO}_{2}$ at $25^{\circ} \mathrm{C}$ for 48 hours ( 8 hours at LSCE in the Finnigan equilibration device). Equilibrated $\mathrm{CO}_{2}$ was 

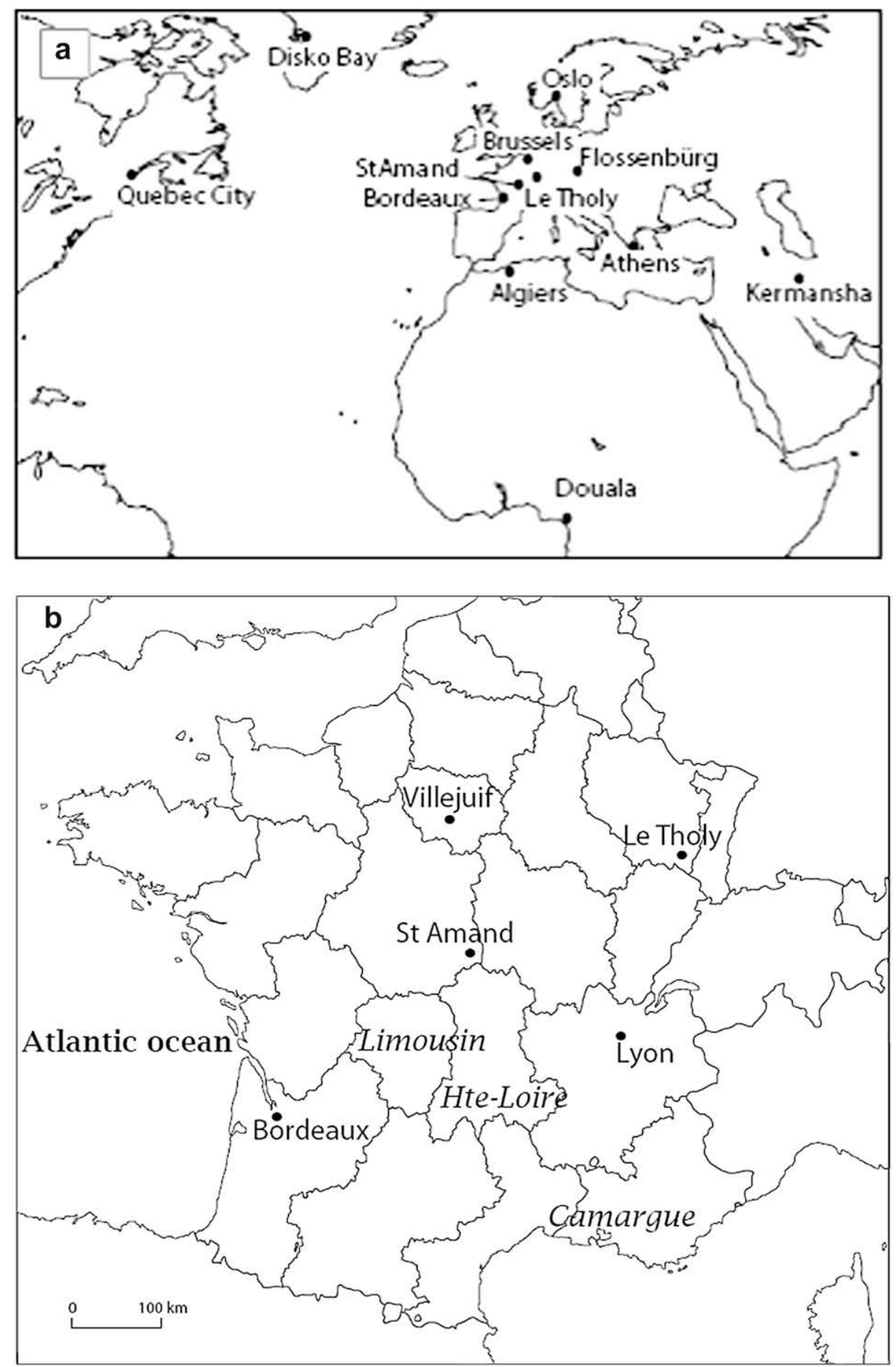

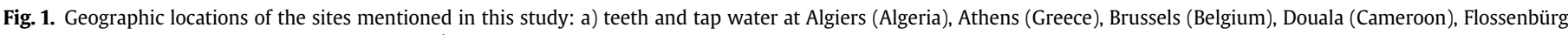

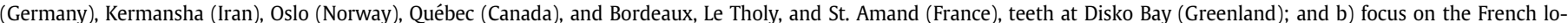

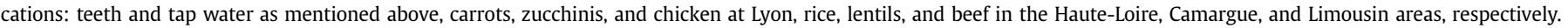

then analyzed with a GV IsoPrime ${ }^{\mathrm{TM}}$, a GV PRISM II stable isotope ratio mass spectrometer at the University of Lyon, or a THERMO Finnigan MAT 252 stable isotope ratio mass spectrometer at LSCE, Gif/Yvette. External reproducibility of oxygen isotope measurements is close to $0.05 \%$. Tap water samples were not collected at Disko Bay (Greenland).

In addition, for each sampling site, the $\delta^{18} \mathrm{O}$ value of precipitation was estimated from a global dataset according to an algorithm developed by Bowen and Wilkinson (2002) and refined by Bowen and Revenaugh (2003). The dataset is derived from the International Energy Association/World Meteorological Organization
Global Network for Isotopes in Precipitation by using the Online Isotopes in Precipitation Calculator (OIPC; version updated in 2004).

We have chosen to use both tap water and OIPC estimates for $\delta^{18} \mathrm{O}$ to consider how these two may differ and which may be the more appropriate proxy for modeling past $\delta^{18} \mathrm{O}$ levels. We prefer tap water because we believe that in the past humans likely utilized surface water sources, and at present, the tap water of most human beings is pumped from shallow aquifers supplied by precipitation. The residence time of the water in these aquifers is on the order of several years (e.g., Jacques, 1996). As a result, most aquifers tend to 
resemble the weighted mean rainfall of an area within relatively narrow limits (Clark and Fritz, 1997; Darling, 2004). In some of our studied areas, however, tap water is not derived from local shallow ground waters, but from distant lakes higher in altitude than the areas of water use. In Algiers (alt. $25 \mathrm{~m}$ ), the tap water is supplied mainly by the Kaddara Dam reservoir that collects water at $350 \mathrm{~m}$ above sea level. In Athens, Greece (alt. $28 \mathrm{~m}$ ), the Mornos Lake, at $435 \mathrm{~m}$ above sea level, serves as the main storage reservoir. In Bordeaux (France), the tap water is derived from deep ground water approximately 20,000 years old (water supplier "Lyonnaise des Eaux," pers. comm.). Thus, it should prove possible to test our predictions of the offset that should result from these different sources of tap water and the OIPC predictions.

\section{Food water}

To examine the contribution of water from food, various types of food were collected. With the exception of mackerel that was caught in the northern Atlantic, the food came from southeastern and southern Central France in an area relatively close to Lyon, which is also the source of the French tap water used in the experiment. The rice is from Camargue; the beef from Limousin; the chicken, zucchini, and carrots from Lyon city; and the lentils from Haute-Loire (Fig. 1).
Carrots, zucchini, mackerel, beef, and chicken were cut into $1 \mathrm{~mm}$ diameter pieces. Rice and lentil samples were ground and the resulting powders were sieved between $100 \mu \mathrm{m}$ and $500 \mu \mathrm{m}$. Five grams of each food sample (called hereafter "raw food") were boiled in $200 \mathrm{ml}$ distilled water ("initial water") in open beakers for 20 minutes. Cooking water ("final water") and food ("cooked food") were collected after filtration. Sodium azide was added to an aliquot of $1 \mathrm{~g}$ of food to prevent fermentation. Food water was directly equilibrated with $30 \mu$ moles of $\mathrm{CO}_{2}$ for 20 hours at $25^{\circ} \mathrm{C}$ according to the protocol given by Koehler et al. (2000). Oxygen isotope compositions of distilled and cooking waters have been measured using the same equilibration method as for tap waters.

\section{Methods for $\delta^{18} \mathrm{O}_{W} / \delta^{18} \mathrm{O}_{P}$ fractionation equations and modeling} influence of food water on total water

Using a linear regression model, we generated a regression equation to describe the fractionation of $\delta^{18} \mathrm{O}_{\mathrm{W}} / \delta^{18} \mathrm{O}_{\mathrm{P}}$ for our samples. We then compared our equation with those published by Longinelli (1984), Luz et al. (1984; human bones), and Levinson et al. (1987; human teeth) using a single classification Analysis of Covariance (ANCOVA; Sokal and Rohlf, 1995). Statistics were calculated using the BIOMstat program.

Table 1

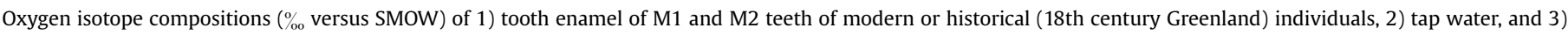
atmospheric precipitation at 12 locations

\begin{tabular}{|c|c|c|c|c|c|c|c|c|}
\hline Country & Site & Lat, Long, Alt ${ }^{\mathrm{a}}$ & $\delta^{18} \mathrm{O}_{\mathrm{P}}$ & $\delta^{18} \mathrm{O}_{\mathrm{P}}$ mean value ${ }^{\mathrm{b}}$ & $\operatorname{SD}(1 \sigma)$ & $\delta^{18} \mathrm{O}_{\mathrm{W}}$ measured $^{\mathrm{b}}$ & $\delta^{18} \mathrm{O}_{\mathrm{W}}$ estimated ${ }^{\mathrm{b}}$ & $\Delta \%$ \\
\hline \multirow[t]{3}{*}{ Cameroon } & Douala & $4.0,9.8,10$ & 18.8 & & & & & \\
\hline & & & 18.5 & & & & & \\
\hline & “ “ & & 18.2 & 18.5 & 0.3 & -3.4 & -3.2 & -0.2 \\
\hline \multirow[t]{3}{*}{ Algeria } & Algiers & $36.7,3.3,25$ & 17.5 & & & & & \\
\hline & & & 16.7 & & & & & \\
\hline & “" & & 17.6 & 17.3 & 0.5 & -6.1 & -4.5 & -1.6 \\
\hline \multirow[t]{4}{*}{ Iran } & Kermanshah & $34.3,47.2,1320$ & 18.2 & & & & & \\
\hline & & & 18.4 & 18.3 & 0.2 & -7.0 & -7.3 & 0.3 \\
\hline & & & $17.7^{\mathrm{c}}$ & & & & & \\
\hline & & & $17.6^{\mathrm{c}}$ & & & & & \\
\hline Greece & Athens & $37.9,23.7,28$ & 16.9 & 16.9 & & -7.9 & -6.2 & -1.7 \\
\hline \multirow[t]{6}{*}{ France } & Le Tholy ${ }^{\mathrm{d}}$ & $48.1,6.7,740$ & 17.0 & & & & & \\
\hline & “، & & 17.3 & & & & & \\
\hline & ““ & & 17.3 & & & & & \\
\hline & ““ & & 16.3 & & & & & \\
\hline & “، & & 16.2 & & & & & \\
\hline & ““ & & 16.4 & 16.7 & 0.5 & -8.5 & -8.9 & 0.4 \\
\hline France & Bordeaux & $44.8,0.7,49$ & 18.3 & 18.3 & & -8.1 & -6.2 & -1.9 \\
\hline France & St. Amand & $46.7,2.5,162$ & 17.3 & 17.3 & & -6.5 & -7.3 & 0.8 \\
\hline \multirow[t]{9}{*}{ Belgium } & Brussels & $50.9,4.5,55$ & 17.0 & & & & & \\
\hline & ““ & & 15.9 & & & & & \\
\hline & ““ “ & & 16.6 & & & & & \\
\hline & ““” & & 16.5 & & & & & \\
\hline & “، & & 16.5 & & & & & \\
\hline & ““ & & 17.5 & & & & & \\
\hline & ““ & & 16.9 & & & & & \\
\hline & ““” & & 16.7 & & & & & \\
\hline & “، & & 16.5 & 16.7 & 0.4 & -7.6 & -8.0 & 0.4 \\
\hline Germany & Flossenbürg & $49.5,12.5,650$ & 16.4 & 16.4 & & -10.1 & -9.4 & -0.7 \\
\hline \multirow[t]{5}{*}{ Canada } & Québec City ${ }^{\mathrm{d}}$ & 46.7, $-71.4,110$ & 14.1 & & & & & \\
\hline & “ “ & & 15.0 & & & & & \\
\hline & “، & & 15.3 & & & & & \\
\hline & “، & & 14.4 & & & & & \\
\hline & “ “ & & 15.3 & 14.8 & 0.5 & -11.0 & -11.4 & 0.4 \\
\hline Norway & Oslo & $59.9,10.7,10$ & 15.1 & 15.1 & & -10.5 & -10.8 & 0.3 \\
\hline \multirow[t]{3}{*}{ Greenland } & Disko Bay & $70.0,-52.0,1$ & 12.3 & & & & & \\
\hline & “، & & 12.5 & & & & & \\
\hline & “ “ & & 11.0 & 11.9 & 0.8 & n.d. & -17.3 & \\
\hline
\end{tabular}

${ }^{\mathrm{a}}$ Lat $=$ degrees North latitude. Long $=$ degrees East longitude. Alt $=$ altitude in meters

b $\delta^{18} \mathrm{O}_{\mathrm{P}}$ and $\delta^{18} \mathrm{O}_{\mathrm{W}}$ in \%o versus SMOW.

c M3 teeth.

d published in Daux et al. (2005). 

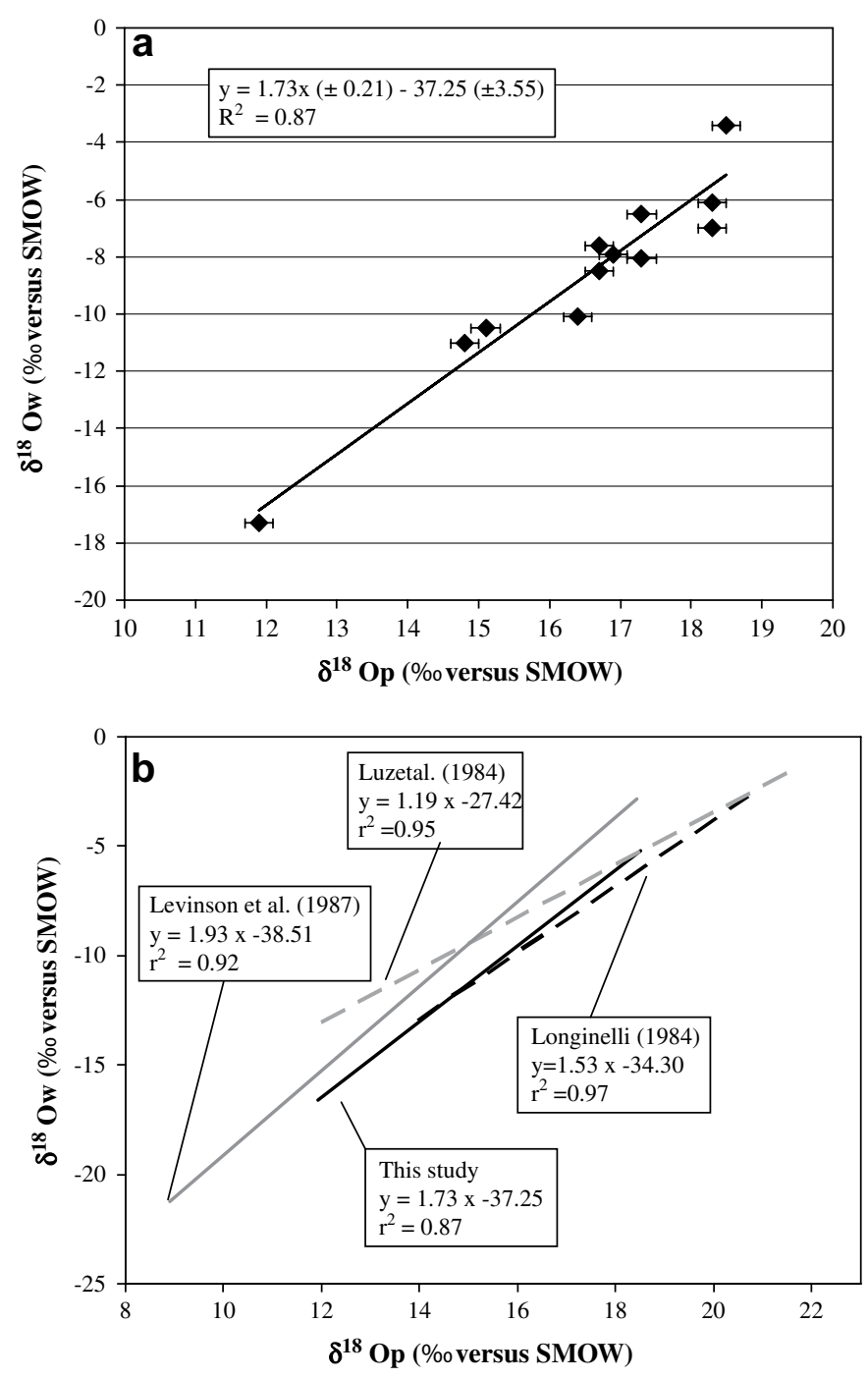

Fig. 2. a) Oxygen isotope fractionation equation computed by using modern human tooth enamel $\left(\delta^{18} \mathrm{O}_{\mathrm{P}}\right)$ and tap water $\left(\delta^{18} \mathrm{O}_{\mathrm{W}}\right)$ from Table 1 (IAEA precipitation data for Disko Bay, Greenland). The error bars correspond to the external reproducibility: $\pm 0.2 \%$ for $\delta^{18} \mathrm{O}_{\mathrm{P}}$ and $\pm 0.05 \%$ for $\delta^{18} \mathrm{O}_{\mathrm{W}}$ (smaller than the symbols); and b) comparison of the equation shown in (a) with those previously published by Longinelli (1984), Luz et al. (1984), and Levinson et al. (1987).

Simple mass balance calculations were performed to quantify the effect of raw and cooked food consumption on the oxygen isotope composition of the total ingested water. We calculated $\Delta \delta^{18} \mathrm{O}$, or the difference between the isotopic composition of the drinking water and of the total ingested water as follows:

$\Delta \delta^{18} \mathrm{O}=\delta^{18} \mathrm{O}_{\mathrm{tot}}-\delta^{18} \mathrm{O}_{\mathrm{W}}$

where:

$$
\begin{aligned}
\delta^{18} \mathrm{O}_{\text {tot }}= & \delta^{18} \mathrm{O}_{\mathrm{W}} \times \mathrm{M}_{\mathrm{W}}+\mathrm{M}_{\mathrm{F}} \times\left(\mathrm{f}_{\mathrm{veg}} \cdot\left[\mathrm{H}_{2} \mathrm{O}\right]_{\mathrm{veg}} \cdot \delta^{18} \mathrm{O}_{\mathrm{veg}}\right. \\
& \left.+\mathrm{f}_{\mathrm{cl}}\left[\mathrm{H}_{2} \mathrm{O}\right]_{\mathrm{cl}} \delta^{18} \mathrm{O}_{\mathrm{cl}}+\mathrm{f}_{\mathrm{mf}}\left[\mathrm{H}_{2} \mathrm{O}\right]_{\mathrm{mf}} \delta^{18} \mathrm{O}_{\mathrm{mf}}\right) / \mathrm{M}_{\mathrm{tot}},
\end{aligned}
$$

and

$\mathrm{M}_{\text {tot }}=\mathrm{M}_{\mathrm{W}}+\mathrm{M}_{\mathrm{F}} \times \mathrm{f}_{\mathrm{veg}}\left[\mathrm{H}_{2} \mathrm{O}\right]_{\mathrm{veg}}+\mathrm{f}_{\mathrm{cl}}\left[\mathrm{H}_{2} \mathrm{O}\right]_{\mathrm{cl}}+\mathrm{f}_{\mathrm{mf}}\left[\mathrm{H}_{2} \mathrm{O}\right]_{\mathrm{mf}}$.

$M_{F}$ and $M_{W}$ are the masses of daily ingested drinking water and total food (assumed to be constant); $\mathrm{M}_{\mathrm{tot}}$ is the mass of water ingested (as a liquid plus in solid food); $f_{v e g}, f_{c l}, f_{m f}$ are the fractions of vegetables, cereals and legumes, and of meat and fish in the diet $\left(f_{v e g}+f_{c l}+f_{m f}=1\right)$; and $\left[\mathrm{H}_{2} \mathrm{O}\right]_{v e g},\left[\mathrm{H}_{2} \mathrm{O}\right]_{c l}$, and $\left[\mathrm{H}_{2} \mathrm{O}\right]_{m f}$ are the water contents of these food categories.

\section{Results}

Oxygen isotope compositions of tooth enamel $\left(\delta^{18} \mathrm{O}_{P}\right)$ and drinking water

The oxygen isotope ratios of tooth enamel from human beings measured in this study range from $11.9 \%$ (Greenland) to $18.5 \%$ (Cameroon) with a corresponding water isotopic range from $-17.3 \%$ to $-3.4 \%$ (Table 1 ). The $1 \sigma$ standard deviations, calculated for the seven sites where at least three individuals have been sampled, range from $0.3 \%$ to $0.8 \%$, indicating an isotopic variability larger than the analytical uncertainty $(1 \sigma=0.2 \%)$.

As predicted, the relationship between tap water and OIPC $\delta{ }^{18} \mathrm{O}$ values is generally good (not exceeding $0.8 \%$ ), but diverges in areas where tap water does not sample shallow aquifers. Our samples from Algiers, Athens, and Bordeaux differ by 1.6 and $1.7 \%$ between the oxygen isotopic values of their tap waters and of OIPC estimates of present day rain in each region (Table 1 ). We discuss the causes of these differences below.

\section{Fractionation equations: $\delta^{18} O_{W}$ versus $\delta^{18} O_{P}$}

Because of the differences in tap water and OIPC values, the $\delta^{18} \mathrm{O}_{\mathrm{W}}$ versus $\delta^{18} \mathrm{O}_{\mathrm{P}}$ regressions yield slightly different isotopic fractionation equations when using tap water values (OIPC estimate is used for Disko Bay; equation 4; Fig. 2a; Table 2) or the OIPC precipitation database (equation 5; Table 2). The ordinary least squares analysis of the data produces the following equations:

$\delta^{18} \mathrm{O}_{\mathrm{W}}=1.73( \pm 0.21) \times \delta^{18} \mathrm{O}_{\mathrm{P}}-37.25( \pm 3.55)$

$\left(n=12 ; \mathrm{R}^{2}=0.87 ; \mathrm{p}\left[\mathrm{H}_{0}: \mathrm{R}^{2}=0\right]=1 \times 10^{-5}\right)$,

and

$\delta^{18} \mathrm{O}_{\mathrm{W}}=1.70( \pm 0.22) \times \delta^{18} \mathrm{O}_{\mathrm{P}}-39.28( \pm 3.68)$

$\left(n=12 ; \mathrm{R}^{2}=0.88 ; \mathrm{p}\left[\mathrm{H}_{0}: \mathrm{R}^{2}=0\right]=7 \times 10^{-6}\right)$

The Greenlandic sample (Disko Bay) lies at the extreme of the correlation. Therefore, it exerts a large influence on the slope of the regression line and on the value of the correlation coefficient (see Table 2). The Greenland sample corresponds to Inuit people who lived during the 18th century. The value of the $\delta^{18} \mathrm{O}_{\mathrm{W}}$ at Disko Bay at this time may have been different from the present day. We therefore explore if this uncertainty regarding the $\delta^{18} \mathrm{O}_{\mathrm{W}}$ must be seen as a motive for excluding the sample.

The variation through time of the isotopic composition of oxygen in Greenland precipitation can be estimated from ice cores. The data reported by Andersen et al. (2006), which are calculated by stacking the record at Dye-3, GRIP, and GNIP drilling sites, represent an integrated North-South value of the isotopic composition of the precipitation (data available on http://icecores.dk). These data are expressed as anomalies, (i.e., differences to the mean calculated from the entire period; S.O. Rasmussen, pers. comm.). The mean values of the $\delta^{18} \mathrm{O}_{\mathrm{W}}$ during the 18th and 20th centuries $(\mathrm{m} \pm 1 \sigma$ : $-0.089 \% \pm 0.3805$ and $-0.005 \pm 0.2237$, respectively) are not significantly different at a $95 \%$ level of confidence (unequal variance Welch test: $t=1.56$, d.f. $=173, p=0.12$ ). Therefore, if differences exist between the $\delta^{18} \mathrm{O}_{\mathrm{P}}$ of the Inuits of the 18 th and of the 20th centuries, they are not due to different oxygen compositions of the precipitation. In addition, this sample is clearly not an outlier when 
Table 2

Regression and correlation parameter estimates for the linear models $\delta^{18} \mathrm{O}_{\mathrm{W}}=\left(a \times \delta^{18} \mathrm{O}_{\mathrm{P}}\right)+b$ associated to the available individual sets of $\delta^{18} \mathrm{O}$-values ${ }^{\mathrm{a}}$

\begin{tabular}{|c|c|c|c|c|c|c|c|c|c|}
\hline & \multirow[t]{2}{*}{$\mathrm{N}$} & \multicolumn{3}{|l|}{ Slope } & \multicolumn{3}{|c|}{ Intercept } & \multicolumn{2}{|c|}{ Correlation } \\
\hline & & Mean & SE & SE/Mean \% & Mean & SE & SE/Mean \% & $\mathrm{R}$ & p-value ${ }^{a}$ \\
\hline Longinelli (1984) & 10 & 1.53 & 0.10 & 6.5 & -34.30 & 1.81 & 5.3 & 0.97 & $4 \times 10^{-7}$ \\
\hline Luz et al. (1984) & 6 & 1.20 & 0.19 & 15.8 & -27.42 & 3.05 & 11.1 & 0.95 & $3 \times 10^{-3}$ \\
\hline Levinson et al. (1987) & 14 & 1.93 & 0.18 & 9.3 & -38.51 & 2.53 & 6.6 & 0.92 & $1 \times 10^{-7}$ \\
\hline This study-tap water except for Disko Bay (OIPC estimate) & 12 & 1.73 & 0.21 & 12.1 & -37.25 & 3.55 & 9.5 & 0.88 & $1 \times 10^{-5}$ \\
\hline This study without the Disko Bay sample-tap water & 11 & 1.49 & 0.35 & 23.5 & -33.08 & 5.87 & 17.7 & 0.67 & $2 \times 10^{-3}$ \\
\hline This study-OIPC estimates ${ }^{b}$ & 12 & 1.87 & 0.22 & 11.8 & -39.28 & 3.68 & 9.4 & 0.89 & $7 \times 10^{-6}$ \\
\hline This study without the Disko Bay sample-OIPC estimates ${ }^{\mathrm{b}}$ & 11 & 1.75 & 0.37 & 21.1 & -37.21 & 6.29 & 16.9 & 0.71 & $1 \times 10^{-3}$ \\
\hline Overall equation & 42 & 1.54 & 0.09 & 5.8 & -33.72 & 1.51 & 4.5 & 0.87 & $2 \times 10^{-19}$ \\
\hline
\end{tabular}

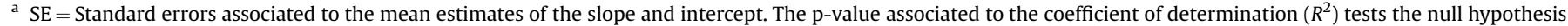
$\mathrm{H}_{0}: R^{2}=0$.

b Not used in the overall equation.

considering all published data simultaneously (see Discussion). So, we conclude that there is no obvious reason to exclude the Greenlandic samples from our dataset. However, we also provide all the parameters of the regression equations calculated without the Greenlandic sample in Table 2.

The regression equation (4) presented here differs slightly from those published by Longinelli (1984), Luz et al. (1984; human bones), and Levinson et al. (1987; human teeth) (Table 2, Fig. 2b). The application of these various equations to extreme conditions can generate differences of several \% in the estimates of $\delta^{18} \mathrm{O}_{\mathrm{W}}$ values. Nevertheless, a single classification Analysis of Covariance (ANCOVA; Sokal and Rohlf, 1995) indicates that these four models do not differ from each other at a $\alpha=0.01$ significance level (Table 3), a more secure and preferable type-I error rate than the usual $\alpha=0.05$ error rate. This stricter criterion was preferred because: 1) different analytical techniques have been used by authors, 2) there are measurement errors and betweenmeasures variability for most points, and 3) the number of points available in each of the four samples is small.

Consequently, the linear models calculated for the four sets of $\delta^{18} \mathrm{O}_{\mathrm{W}} / \delta^{18} \mathrm{O}_{\mathrm{P}}$ values (Longinelli, 1984; Luz et al., 1984; Levinson et al., 1987; this study) can be considered as random estimates of a unique $\delta^{18} \mathrm{O}_{\mathrm{W}} / \delta^{18} \mathrm{O}_{\mathrm{P}}$ linear relation that can be more accurately estimated by compiling the four sets into a single super-sample $(n=42)$. The least squares analysis of the whole set leads to the following overall equation (see also Fig. 3):

$\delta^{18} \mathrm{O}_{\mathrm{W}}=1.54( \pm 0.09) \times \delta^{18} \mathrm{O}_{\mathrm{P}}-33.72( \pm 1.51)$

$\left(\mathrm{R}^{2}=0.87: \mathrm{p}\left[\mathrm{H}_{0}: \mathrm{R}^{2}=0\right]=2 \times 10^{-19}\right)$

\section{Oxygen isotope composition of food water}

The oxygen isotope compositions of the waters used for the experiment are ${ }^{18} \mathrm{O}$-depleted $(-10$. or $-11.2 \%$; water a) or enriched $(7.8 \%$; water b) relative to SMOW (Table 4). While cooking, two chemical reactions operate: first, the water evaporates and becomes ${ }^{18} \mathrm{O}$ enriched, and second, there are exchanges of $\mathrm{H}_{2} \mathrm{O}$ molecules between cooking water and food water. As a result, the oxygen isotopic compositions of the water of the cooked food

Table 3

Results of the single classification ANCOVA

\begin{tabular}{|c|c|c|c|c|c|c|}
\hline & \multicolumn{2}{|l|}{ Among groups } & \multicolumn{2}{|l|}{ Within groups } & \multicolumn{2}{|l|}{ Statistics } \\
\hline & Sum of squares & d.f. & Sum of squares & d.f. & Fisher F & p-value ${ }^{b}$ \\
\hline Slopes & 23.678 & 3 & 100.338 & 37 & 2.91 & 0.048 \\
\hline Intercepts & 23.166 & 3 & 100.338 & 40 & 3.08 & 0.042 \\
\hline
\end{tabular}

a.f. = degrees of freedom.

b Associated to the slope and intercept comparisons indicating that the four individual $\delta^{18} \mathrm{O}_{\mathrm{p}}-\delta^{18} \mathrm{O}_{\mathrm{w}}$ linear models do not differ significantly from each other at the $\alpha=0.01$ significance level (see text for comment) $\left(\delta^{18} \mathrm{O}_{\mathrm{cf}}\right)$ and of the final water $\left(\delta^{18} \mathrm{O}_{\mathrm{fw}}\right)$ are close to each other and higher than the $\delta^{18} \mathrm{O}$ of the initial water. The $\delta^{18} \mathrm{O}$ of the water of the cooked food is closer to the value of the water of the raw food for initially highly-hydrated food (zucchinis and carrots; see Table 4) than for drier food (mackerel, beef, chicken, rice, lentils). The apparent isotopic fractionation between the water of the cooked food and the initial water $\left(\delta^{18} \mathrm{O}_{\mathrm{cf}}-\delta^{18} \mathrm{O}_{\mathrm{iw}}\right.$ in Table 4$)$ ranges from $1.2 \%$ to $6.2 \%$. The highest values are observed for vegetables.

Modeling the impact of solid food on the oxygen isotopic composition of ingested water

The values of $\Delta \delta^{18} \mathrm{O}$ calculated according to equation 1, using the isotopic compositions of the tap water at Lyon $(-10.5 \%)$ and the parameters reported in Table 5, are shown in Fig. 4a (raw food) and $4 \mathrm{~b}$ (cooked food). The vegetables, legumes, cereals, meat, and fish analyzed in this study were grown at some distance from the place where the water was collected in Lyon (see Food water). Thus, their oxygen isotopic composition is not linked to that of the local water (carrots, zucchini, and chicken are excepted as they are grown and farmed in the Lyon area). However, all foods originate from southeastern and southern Central France and cannot differ much isotopically from those of the Lyon area.

\section{Discussion}

\section{Variability in the oxygen isotopic composition of drinking water}

In most cases, the oxygen isotope compositions of measured tap waters differ only slightly from the yearly mean oxygen isotope

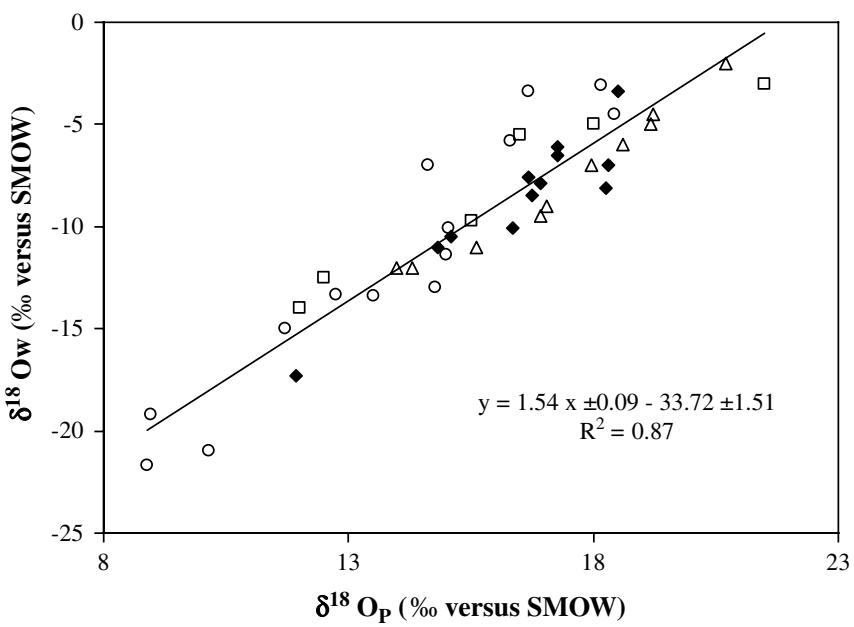

Fig. 3. Oxygen isotope fractionation equation resulting from the compilation of all the available data. Filled diamonds: this study; open triangles: Longinelli (1984); open circles: Levinson et al. (1987); open squares: Luz et al. (1984). 
Table 4

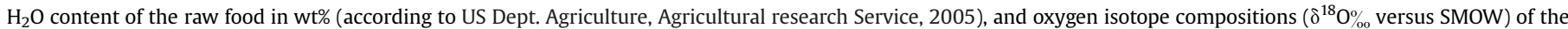
water in the raw and in the cooked food initial and final waters. $\Delta_{\mathrm{c} \text {-iw }}=\delta^{18} \mathrm{O}_{\text {cooked food }}-\delta^{18} \mathrm{O}_{\text {initial water }}$

\begin{tabular}{|c|c|c|c|c|c|c|c|c|c|}
\hline & Zucchinis & Carrots & Mackerel & Beef & Chicken & Rice (a) & Rice (b) & Lentils (a) & Lentils (b) \\
\hline $\begin{array}{l}\mathrm{H}_{2} \mathrm{O} \text { wt\% } \\
\delta{ }^{18} \mathrm{O}\end{array}$ & 95 & 88 & 63 & 65 & 75 & 10 & 10 & 10 & 10 \\
\hline Raw food & -4.0 & -2.9 & -2.1 & -1.7 & -3.7 & -5.9 & -5.9 & 0.8 & 0.8 \\
\hline Initial water & -10.5 & -10.5 & -11.2 & -10.5 & -10.5 & -10.5 & 7.8 & -10.5 & 7.8 \\
\hline Cooked food & -4.3 & -4.3 & -7.5 & -7.7 & -8.3 & -7.9 & 9.7 & -7.9 & 9.0 \\
\hline Final water & -6.4 & -5.4 & -9.5 & -8.8 & -9.9 & -8.4 & 9.9 & -8.4 & 9.3 \\
\hline$\delta^{18} \mathrm{O}_{\mathrm{cf}}-\delta^{18} \mathrm{O}_{\mathrm{iw}}$ & 6.2 & 6.2 & 3.7 & 2.8 & 2.2 & 2.6 & 1.9 & 2.6 & 1.2 \\
\hline
\end{tabular}

compositions of precipitation calculated with the OIPC (Table 1). In Athens, Algiers, and Bordeaux there are larger discrepancies. The 1.6 and $1.7 \%$ differences between the oxygen isotopic values of tap waters and of OIPC estimates of present day rain at Algiers and Athens (Table 1) may be ascribed, at least partly, to an altitude influence. In the Mediterranean area, an altitude effect of -0.2 to $-0.4 \% / 100 \mathrm{~m}$ has been measured (Bortolami et al., 1978; Leontiadis et al., 1996). A mean $-0.3 \% / 100 \mathrm{~m}$ lapse rate would produce a $\delta^{18} \mathrm{O}$ decrease of 1.0 to $1.3 \%$. The $\delta^{18} \mathrm{O}$ value from Bordeaux (France) is $1.6 \%$ lower than the OIPC estimates for the area. If a $\delta^{18} \mathrm{O} / \mathrm{T}$ gradient of $0.6 \% /{ }^{\circ} \mathrm{C}$ (e.g., Von Grafenstein et al., 1996; Fricke and O'Neil, 1999) is considered, this difference corresponds to an atmospheric temperature 20,000 years ago that was $3^{\circ} \mathrm{C}$ lower than today. During the Last Glacial Maximum, annual temperatures in this area are thought to have been ca. $12{ }^{\circ} \mathrm{C}$ lower (Jost et al., 2005; Kageyama et al., 2007), but the lack of precision of the dating and the likely mixing of waters of different ages preclude further comparison. In some areas, tap waters derive from tributaries or rivers that are not buffered by large reservoirs and are characterized by seasonal isotopic variations (e.g., Chao et al., 1996; Darling, 2004). In those cases, a one-off sampling is not representative of the yearly mean. The good correlation between our measured tap waters and the OIPC estimates $\left(R^{2}=0.89\right)$ demonstrates that this effect, if any, is limited.

Even though the fractionation equations obtained with the tap waters and OIPC estimates of precipitations resemble each other, we argue, for the reasons stated above, that local measured waters (equation 4) should be preferred to estimated precipitations. Because drinking water represents from 0.6 to $0.75 \%$ of the total water ingested by a human, drinking water has a larger influence on $\delta^{18} \mathrm{O}_{\mathrm{P}}$. As tap water may differ from environmental water in modern countries, the isotope composition of the oxygen input flux is closer to the composition of the tap water. Therefore, the $\delta^{18} \mathrm{O}_{\mathrm{P}} / \delta^{18} \mathrm{O}_{\mathrm{W}}$ fractionation equation based on tap water is more appropriate. In historical and prehistorical times, human beings may have derived much of their water from surface water sources (lakes, rivers, streams), and hence, some of the limitations presented above may not be significant at these times (deep water catchments are less likely for instance). However, a range of factors (e.g., preservation of the "altitude signature" downstream for rivers, evaporative fractionation) may influence the isotopic composition of surface waters. Therefore, correcting back ancient teeth $\delta^{18} \mathrm{O}_{\mathrm{P}}$ signal to local rainfall isotopic composition may not be straightforward.

Table 5

Parameters of the mass balance calculation shown in Fig. 4

\begin{tabular}{llll}
\hline Parameter & Raw & Cooked & Reference \\
\hline$\left[\mathrm{H}_{2} \mathrm{O}\right]_{\text {veg }}$ (weight \%) & 90 & 90 & US Dept. Agriculture \\
{$\left[\mathrm{H}_{2} \mathrm{O}\right]_{\mathrm{cl}}($ weight \%) } & 10 & 72 & US Dept. Agriculture \\
{$\left[\mathrm{H}_{2} \mathrm{O}\right]_{\mathrm{mf}}($ weight \%) } & 65 & 65 & US Dept. Agriculture \\
$\delta^{18} \mathrm{O}_{\mathrm{veg}}(\%)$ & -3.5 & -4.3 & This work \\
$\delta^{18} \mathrm{O}_{\mathrm{cl}}(\%)$ & -2.6 & -7.9 & This work \\
$\delta^{18} \mathrm{O}_{\mathrm{mf}}(\%)$ & -2.5 & -7.8 & This work \\
$\mathrm{M}_{\mathrm{w}}(\mathrm{Kg})$ & 2.0 & & Howard and Bartram, 2003 \\
$\mathrm{M}_{\mathrm{F}}(\mathrm{Kg})$ & 0.982 & & US Dept. Agriculture \\
\hline
\end{tabular}

\section{Compatibility of the different $\delta^{18} \mathrm{O}_{W} / \delta^{18} \mathrm{O}_{P}$ fractionation equations}

When compared to the four initial models (Table 2), the overall model (equation 6) shows markedly reduced uncertainties allowing more accurate predictions (lower associated standard error) of $\delta^{18} \mathrm{O}_{\mathrm{W}}$ values on the entire range of sampled $\delta^{18} \mathrm{O}_{\mathrm{p}}$ values (Table 6). For instance, for $\delta^{18} \mathrm{O}_{\mathrm{p}}$ values in the range of 12.5-19, where most of the individuals have been sampled, using the overall model allows the prediction of $\delta^{18} \mathrm{O}_{\mathrm{W}}$ values in the range from -4 to -14.5 with a $95 \%$ confidence interval $<2 \delta$ units (i.e., $1 \sigma$ prediction error $<0.5$ $\delta$ unit). Let us note that the 18th century Greenlandic sample, the representativeness of which was questioned earlier, is not an outlier in the overall scatter plot (Fig. 3).

Influence of the dietary behavior on the oxygen isotopic composition of enamel

Although oxygen isotopic signature of tooth enamel is related to drinking water, the inter-individual variability in the enamel composition is quite important $(\mathrm{SD}=0.5 \%$ on average, up to $0.8 \%$ o at Disko Bay). Food and cooking may play a part in this variation since the water absorbed by consumers ("total water") is the sum of drinking water and water ingested from solid food. Some food (cereals, legumes) contains only a few wt \% water, whereas most vegetables are up to $95 \%$ water by weight (Table 4 ). Plants and meat are ${ }^{18} \mathrm{O}$-enriched compared to meteoric water (e.g., Schmidt et al., 2001; Thiem et al., 2004). Therefore, the total water ingested by consumers may be ${ }^{18} \mathrm{O}$-enriched compared to the meteoric water of their living place.

Kohn (1996) has shown the effect of diet on the oxygen isotopic composition of tooth enamel by studying some East African herbivores. The consumption of $C_{3}$ versus $C_{4}$ plants, in particular, accounts for at least a part of the isotopic interspecific variability. In humans, cooking complicates the relationship. In boiling, food becomes hydrated from the cooking water, which is ${ }^{18} \mathrm{O}$-enriched through progressive evaporation. According to our data, the $\delta^{18} \mathrm{O}$ of raw and cooked food are similar to each other if the food is initially hydrated (e.g., carrots, zucchinis). Therefore, the effect of such food consumption on the isotopic composition of the total water is more or less the same whether the food is raw or cooked. Cereals and legumes (rice, lentils) and meat and fish, which are seldom eaten raw, incorporate significant amounts of ${ }^{18} \mathrm{O}$-enriched water during cooking (Tables 4 and 5). Therefore, their consumption is likely to increase the $\delta^{18} \mathrm{O}$ of a person's total water.

According to our mass balance calculations, the maximum ${ }^{18} \mathrm{O}-$ enrichment of the total water compared to the drinking water is ca. $2 \%$ (corresponding to $1.1 \%$ in human enamel). This maximum enrichment occurs in a raw food diet with very high proportions of meat or vegetables, or in diets mainly based on cooked vegetables (Fig. 4). Therefore, at any given place, the water ingested by human beings via solid foods, whether it is raw or cooked, should not be richer in ${ }^{18} \mathrm{O}$ than is the total water ingested by herbivorous animals of the same place whose diet is composed of 

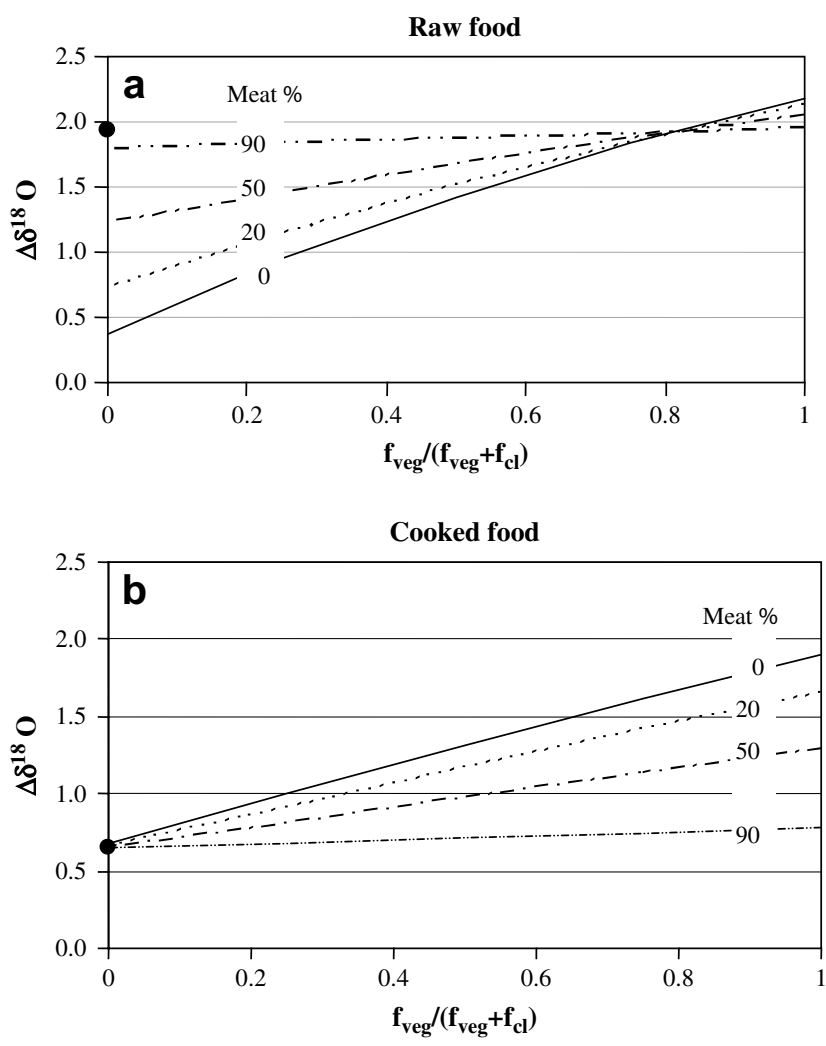

Fig. 4. Modeled isotopic enrichment of the total ingested water $\left(\Delta \delta^{18} 0\right.$ in $\%$ versus SMOW). Three categories of food are considered: meat and fish $(\mathrm{mf})$, vegetables and fruits (veg) and cereals and legumes $(\mathrm{cl})$. The figures on the lines correspond to the fractions of meat + fish in the total food $\left(f_{m f}\right)$. The figures of the $\mathrm{x}$-axis represent the fractions of vegetables in the remaining part of the food $\left(f_{v e g} /\left(f_{v e g}+f_{c l}\right)\right)$.

raw plants (tree-leaves, fruits, and grass). Iacumin et al. (2004) have calculated the oxygen isotopic composition of precipitation $\left(\delta^{18} \mathrm{OW}_{\mathrm{W}}\right)$ 5,000 to 500 years ago in European Russia from humans and herbivorous animals (sheep, horse, deer). They observed that the $\delta^{18} \mathrm{O}_{\mathrm{W}}$ calculated from the herbivores was higher than that calculated from the human samples. They attributed this discrepancy to different drinking water sources or to diets. However, according to our calculations the effects of herbivorous versus omnivorous diets on the isotopic composition of the ingested water may be responsible for the observed difference.

Current human diet relies mainly on cooked food. Although the percentages of meat-fish, cereals-legumes, and vegetables-fruits consumed vary from individual to individual, mean values of 20 $30 \%$ for the meat-fish component, $30-40 \%$ for the vegetables-fruits component, and $30-50 \%$ for the cereals-legumes components $\left(\mathrm{f}_{\mathrm{veg}}\right)$ $\left(\mathrm{f}_{\mathrm{veg}}+\mathrm{f}_{\mathrm{cl}}\right)$ of 0.4 to 0.6$)$ are in general agreement with the statistics produced by the Food and Agriculture Organization (http:// www.fao.org/). Such a diet induces a difference between the drinking water and the total ingested water of +1.05 to $+1.20 \%$ (Fig. 4b). This difference corresponds to a shift in the $\delta^{18} \mathrm{O}_{\mathrm{p}}$ ranging from +0.6 to $+0.7 \%$. Although there is the variability in the origin, amount, and proportion of the various types of food consumed, these figures show that the $\delta^{18} \mathrm{O}_{\mathrm{p}}$ recorded in tooth enamel of contemporaneous people is likely shifted towards values slightly higher than the values that would result from their drinking water alone. It is not possible to correct the measured $\delta^{18} \mathrm{O}_{\mathrm{P}}$ data for the effect of solid food consumption because the diets of the individuals are not known and may differ from one another. According to the estimation presented above, the interindividual variability of the $\delta^{18} \mathrm{O}_{\mathrm{P}}$ values (SD ca. $\pm 0.5 \%$ in this study; Table 1 ) may be ascribed only partly to intraindividual dietary differences (0.7-0.6 $=0.1 \%$ from the calculation above).

The regression of $\delta^{18} \mathrm{O}_{\mathrm{W}}$ on $\delta^{18} \mathrm{O}_{\mathrm{P}}$ (as in equation 6) implicitly assimilates the $\Delta \delta^{18} \mathrm{O}$ shift, which is controlled by the relative proportions of the food components, to a systematic bias. It follows that the reconstruction of $\delta^{18} \mathrm{O}_{\mathrm{W}}$ from $\delta^{18} \mathrm{O}_{\mathrm{P}}$ yields accurate results if the proportions of an individual's diet are similar to modern proportions. If the $\Delta \delta^{18} \mathrm{O}$ is higher than the contemporaneous value $(1.05-1.20 \%$ ), the application of the regression equation leads to an overestimation of $\delta^{18} \mathrm{O}_{\mathrm{W}}$. An underestimation would result if $\Delta \delta^{18} \mathrm{O}$ is lower.

Archaeological and isotopic evidence suggests that Paleolithic diets varied considerably through time and space. It is far beyond our goal to retrace the history of human diet. However, we can explore the effect on $\Delta \delta^{18} \mathrm{O}$ of some specific diets (meat-rich and cereal-poor) that may approximate the extremes during the Paleolithic.

\section{The influence of carnivory and cereal free diets in Neandertals and modern humans}

The Neandertal diet has been argued to be essentially carnivorous (Fizet et al., 1995; Richards et al., 2000; Bocherens et al., 2005; Balter and Simon, 2006). If we take an extreme value, a raw diet composed of more than $90 \%$ fish and meat would have a $\Delta \delta^{18} \mathrm{O}$ that is $+1.9 \%$, or slightly higher than the modern diet (Fig. $4 \mathrm{a}$ ). For the boiled equivalent, the shift decreases to $+0.6 \%$. Archaeological sites deliver few clues about cooking practices. As a result, little is known about Neandertal recipes, but boiling may not have been a widespread practice. Indeed, it is likely that some meat was cooked on broach or cured (Kozlowski and Kozlowski, 1996; PatouMathis, 2006; methods referred to hereafter as "dry"). Due to the fact that ${ }^{18} \mathrm{O}$ preferentially remains and is enriched during evaporation, the $\delta^{18} \mathrm{O}$ of the meat water increases with drying (Franke et al., 2007). The consumption of dry cooked meat induces a $\Delta \delta^{18} \mathrm{O}$ larger than the shift corresponding to raw meat or to boiled or braised meat (i.e., $>1.9 \%$ ). Therefore, if the Neandertal diet is assumed to rely mainly on dry-cooked meat, the isotopic enrichment would be larger than the modern shift. As a consequence, using $\delta^{18} \mathrm{O}_{\mathrm{P}}$ of Neandertal teeth to reconstruct the oxygen isotopic

Table 6

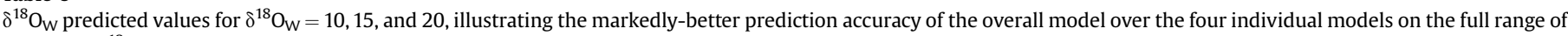
measured $\delta^{18} \mathrm{O}_{\mathrm{P}}$-values. Mean and 95\% confidence intervals in brackets

\begin{tabular}{|c|c|c|c|c|}
\hline & \multicolumn{4}{|c|}{$\delta^{18} \mathrm{O}_{\mathrm{P}}$} \\
\hline & $n$ & 10 & 15 & 20 \\
\hline Longinelli (1984) & 10 & N.A. & $-11.4[-12.4 ;-10.4]$ & $-3.8[-4.9 ;-2.7]$ \\
\hline Luz et al. (1984) & 6 & N.A. & $-9.5[-11.8 ;-7.0]$ & $-3.5[-7.0 ; 0.1]$ \\
\hline Levinson et al. (1987) & 14 & $-19.2[-21.7 ;-16.7]$ & $-9.5[-11.1 ;-8.0]$ & N.A. \\
\hline Daux et al. (This Study) & 12 & N.A. & $-11.3[-12.7 ;-9.8]$ & N.A. \\
\hline Total & 42 & $-18.3[-19.9 ;-16.8]$ & $-10.6[-11.3 ;-9.9]$ & $-2.9[-4.1 ;-1.7]$ \\
\hline
\end{tabular}

N.A. = not available. 
composition of ancient precipitation may overestimate this last parameter. However, roasting meat and fish on hot stones may also have been a common practice among Neandertal humans. This cooking method may not influence the water content, and correlatively the $\Delta \delta^{18} \mathrm{O}$, as much as the other drying methods. Clearly, more experiments are needed to measure the extent of the isotopic enrichment induced by different dry cooking methods. Additional information about Neandertal diet would also be very valuable to refine these conclusions.

In some areas, cereals were staple foods as early as 23,000 years $\mathrm{BP}$ (wild wheat and barley at Ohalo II site, Israel; Weiss et al., 2004). Cooking is necessary for the processing of cereal grains. A diet containing cooked cereals induces a lower $\Delta \delta^{18} \mathrm{O}$ than a cereal-free diet (Fig. 4b). During most of the Paleolithic times, human diet was cereal free $(\mathrm{fveg} /(\mathrm{fveg}+\mathrm{fcl})=1)$. In these conditions, the isotopic shift ranges between 1.3 and $1.7 \%$ for 50 to $20 \%$ meat and fish; this is 0.10 to $0.65 \%$ higher than the modern shift. Therefore, it can be concluded that the $\delta^{18} \mathrm{O}_{\mathrm{W}}$, deduced from the $\delta^{18} \mathrm{O}_{\mathrm{p}}$ of humans whose diets were cereal free (using equation 6), would be slightly overestimated.

\section{Conclusions}

The oxygen isotope composition of tooth enamel phosphate $\left(\delta^{18} \mathrm{O}_{\mathrm{P}}\right)$ is related to the composition of the water ingested during the time of tooth mineralization. In this study, we propose a fractionation equation $\left(\delta^{18} \mathrm{O}_{\mathrm{P}} / \delta^{18} \mathrm{O}_{\mathrm{W}}\right)$ defined over a large range of isotopic compositions (equation 6). This new equation is characterized by markedly reduced uncertainties allowing lower associated standard error ( $1 \sigma$ prediction error $<0.5 \delta$ unit) of $\delta^{18} \mathrm{O}_{\mathrm{W}}$ values on the entire range (12.5-19) of sampled $\delta^{18} \mathrm{O}_{\mathrm{P}}$ values.

During historical and prehistorical times, humans probably derived much of their drinking water from surface sources. These waters, however, may be different from the mean $\delta^{18} \mathrm{O}$ of rainfall. Therefore, the paleo-environmental significance of the $\delta^{18} \mathrm{OW}_{\mathrm{W}}$ values reconstructed from $\delta^{18} \mathrm{Op}$ may be complicated to infer. Ideally, a full understanding of the hydrological factors at the local scale is necessary to be confident in the validity of the interpretation.

The consumption of solid food (particularly vegetables) tends to increase the $\delta^{18} \mathrm{O}$ of the total water ingested (drink + water in solids) by more than $1 \%$. In meat-rich and cereal-free diets, the difference between the $\delta^{18} \mathrm{O}$ of the total ingested water and the drinking water is slightly higher than a modern diet (containing meat, fish, vegetables, fruits, cereals, and legumes). As a consequence, the oxygen isotopic composition of precipitation deduced from the $\delta^{18} \mathrm{O}_{\mathrm{P}}$ using equation 6 is slightly overestimated when the teeth analyzed belonged to humans whose diets were meat-rich or cereal-free. In the case of a meat-rich diet, this conclusion, however, depends on the type of cooking employed. Only certain kinds of heating that significantly reduce the water content of the meat (curing, cooking on broach) would have a sizable effect on $\delta^{18} \mathrm{O}_{\mathrm{W}}$. More information is needed to refine the estimation of the influence of specific diets on $\delta^{18} \mathrm{O}_{\mathrm{P}}$.

In addition to other isotopic $\left(\delta^{15} \mathrm{~N}, \delta^{13} \mathrm{C}\right)$ or archaeological methods, the analysis of the oxygen isotopic composition of teeth enamel can be used, in an independent manner, to compare the diets of human groups that lived close to each other (drinking water of the same isotopic composition) or to analyze the evolution of culinary practices at some places over climatically stable periods (constant $\delta^{18} \mathrm{O}$ in the drinking water).

\section{Acknowledgements}

We are grateful to Drs. C. Gillet, P. Gaudreault, B. Belmecheri, D. Fontan, T.-P. Brisker, O. Lewden, and N'Tamak; the surgeons of the
"Service de Stomatologie et Chirurgie maxillo-faciale" of the University of Louvain (B); and to an anonymous Iranian surgeon, for assistance in teeth collection. We thank U. Von Grafenstein, S. Belmecheri, M.-J. N'Tamak-Nida, D. Lewden, G. Matias, A. Bergeron, and Shoukou for helping in teeth collection, and B. Daux, E. Mercier, C. Robin, F. Baudin, B. Malaizé, and J.L. Turon for water collection. We are also grateful to M.J. Kohn for providing a comprehensive review of an early version of the paper, and to anonymous reviewers and S. Antón for their constructive remarks. This work was financially supported by the CNRS through the ECLIPSE program.

\section{References}

Altman, P.L., Dittmer, D.S., 1968. Metabolism. Federation of the American Society of Experimental Biologists, Bethesda, MD.

Ambrose, S.H., De Niro, M.J., 1986. Reconstruction of African human diet using bone collagen carbon and nitrogen isotope. Nature 319, 321-324.

Andersen, K.K., Ditlevsen, P.D., Rasmussen, S.O., Clausen, H.B., Vinther, B.M. Johnsen, S.J., Steffensen, J.P., 2006. Retrieving a common accumulation record from Greenland ice cores for the past 1800 years. J. Geophys. Res. 111 (D15), 11.

Balter, V., Simon, L., 2006. Diet and behavior of the Saint-Cézaire Néanderthal inferred from biogeochemical data inversion. J. Hum. Evol. 51, 329-338.

Bocherens, H., Drucker, D.G., Billiou, D., Patou-Mathis, M., Vandermeersch, B., 2005. Isotopic evidence for diet and subsidence pattern of the Saint-Cézaire Neanderthal: review and use of a multi-source mixing model. J. Hum. Evol. 49, 71-87.

Bocherens, H., Fizet, M., Mariotti, A., Lange-Badré, B., Vandermeersch, B., Borel, J.P. Bellon, G., 1991. Isotopic biogeochemistry $\left({ }^{13} \mathrm{C},{ }^{15} \mathrm{~N}\right)$ of fossil vertebrate collagen: implications for the study of fossil food web including Neandertal Man. J. Hum. Evol. 20, 481-492.

Bortolami, G.C., Ricci, B., Zuppi, G.M., 1978. Isotope hydrology of Val Corsiglia, Maritime Alps, Piedmont Italy. Isotope Hydrol. 1, 327-350.

Bowen, G.J., Revenaugh, J., 2003. Interpolating the isotopic composition of modern meteoric precipitation. Water Resour. Res. 39, 1299.

Bowen, G.J., Wilkinson, B., 2002. Spatial distribution of $\delta^{18} \mathrm{O}$ in meteoric precipitation. Geology 30, 315-318.

Chao, Y., Telmer, K., Veizer, J., 1996. Chemical dynamics of the St. Lawrence riverine system: $\delta \mathrm{D}_{\mathrm{H} 2 \mathrm{O}}, \delta^{18} \mathrm{O}_{\mathrm{H} 2 \mathrm{O}}, \delta^{13} \mathrm{C}_{\mathrm{H} 2 \mathrm{O}}, \delta^{34} \mathrm{~S}_{\text {sulfate, and dissolved }}{ }^{87} \mathrm{Sr} /{ }^{86} \mathrm{Sr}$. Geochim. Cosmochim. Acta 60, 851-866.

Clark, I.D., Fritz, P., 1997. Environmental Isotopes in Hydrogeology. Lewis Publishers, Boca Raton, pp. 328.

Crowson, R.A., Showers, W.J., Wright, E.K., Hoering, T.C., 1991. A method for preparation of phosphate samples for oxygen isotope analysis. Anal. Chem. 63 2397-2400.

Darling, W.G., 2004. Hydrological factors in the interpretation of stable isotopic proxy data present and past: a European perspective. Quatern. Sci. Rev. 23, 743770.

Daux, V., Lécuyer, C., Adam, F., Martineau, F., Vimeux, F., 2005. Oxygen isotope composition of human teeth and the record of climate changes in France (Lorraine) during the last 1700 years. Clim. Change 70, 445-464.

Dupras, T.L., Schwarcz, H.P., 2001. Strangers in a strange land: stable isotope evidence for human migration in the Dakhleh Oasis, Egypt. J. Archaeol. Sci. 28, 1199-1208.

Eberhardt, L.L., 1969. Similarity, allometry and food chains. J. Theor. Biol. 24, 43-55.

Epstein, S., Mayeda, T., 1953. Variations of $\delta^{18} \mathrm{O}$ content of water from natural sources. Geochim. Cosmochim. Acta 4, 213.

Evans, J., Stoodley, N., Chenery, C., 2006. A strontium and oxygen isotope assessment of a possible fourth century immigrant population in a Hampshire cemetery, southern England. J. Archaeol. Sci. 33 (2), 265-272.

Firshing, F.H., 1961. Precipitation of silver phosphate from homogeneous solution. Anal. Chem. 33, 873-874.

Fizet, M., Mariotti, A., Bocherens, H., Lange-Badré, B., Vandermeersch, B., Borel, J.P. Bellon, G., 1995. Effect of diet, physiology and climate on carbon and nitrogen stable isotopes of collagen in a Late Pleistocene anthropic palaeoecosystem Marillac, Charente, France. J. Archaeol. Sci. 22, 67-79.

Franke, B., Koslitz, S., Micaux, F., Maury, V., Pfammatter, E., Wunderli, S Gremaud, G., Bosset, J.-O., Hadorn, R., Kreuzer, M., 2007. Tracing the geographic origin of poultry meat and dried beef with oxygen and strontium isotope ratios. Eur. Food Res. Technol, 9. Online.

Fricke, H.C., O'Neil, J.R., 1999. The correlation between ${ }^{18} \mathrm{O} /{ }^{16} \mathrm{O}$ ratios of meteoric water and surface temperature: its use in investigating terrestrial climate change over geologic time. Earth Planet. Sci. Lett. 170, 181-196.

Fricke, H.C., O'Neil, J.R., Lynnerup, N., 1995. Oxygen isotope composition of human tooth enamel from medieval Greenland: linking climate and society. Geology 23, 869-872.

Howard, G., Bartram, J., 2003. Water Supply Surveillance: A Reference Manual. WEDC, Loughborough, UK.

Iacumin, P., Nikolaev, V., Ramigni, M., Longinelli, A., 2004. Oxygen isotopes analyses of mammal bone remains from Holocene sites in European Russia: palaeoclimatic implications. Glob. Planet. Change 40 (1-2), 169-176.

Jacques, G., 1996. Le Cycle de l'Eau. Hachette, Paris, pp. 157. 
Jost, A., Lunt, D., Kageyama, M., Abe-Ouchi, A., Peyron, O., Valdes, P.J., Ramstein, G., 2005. High resolution simulations of the last glacial maximum climate over Europe: a solution to discrepancies with continental paleoclimatic reconstructions? Clim. Dyn. 24, 577-590.

Kageyama, M., Lainé, A., Abe-Ouchi, A., Braconnot, P., Cortijo, E., 2007. Last glacia maximum temperatures over the North Atlantic, Europe and Western Siberia: a comparison between PMIP models, MARGO sea-surface temperatures and pollen-based reconstructions. Quatern. Sci. Rev. 25, 2082-2102.

Koehler, G., Wassenaar, L.I., Hendry, M.J., 2000. An automated technique for measuring $\delta \mathrm{D}$ and $\delta^{18} \mathrm{O}$ values of porewater by direct $\mathrm{CO}_{2}$ - and $\mathrm{H}_{2}$ - equilibration. Anal. Chem. 72, 5659-5664.

Kohn, M.J., 1996. Predicting animal $\delta 180$ : accounting for diet and physiological adaptation. Geochim. Cosmochim. Acta 60, 4811-4829.

Kohn, M.J., Schoeninger, M.J., Valley, J.W., 1996. Herbivore tooth oxygen isotope compositions: effects of diet and physiology. Geochim. Cosmochim. Acta 60, 3889-3896.

Kozlowski, J.K., Kozlowski, S.K., 1996. Le paléolitique en Pologne. Préhistoire de l'Europe 2. Milton, Grenoble, France, pp. 240.

Lécuyer, C., Grandjean, P., Barrat, J.-A., Nolvak, J., Emig, C., Paris, F., Robardet, M., 1998. $\delta^{18} \mathrm{O}$ and REE contents of phosphatic brachiopods: a comparison between modern and lower Paleozoic populations. Geochim. Cosmochim. Acta 48, 385-390.

Lécuyer, C., Grandjean, P., Emig, C.C., 1996. Determination of oxygen isotope fractionation between water and phosphate from living lingulids: potential application to palaeo-environmental studies. Palaeogeogr. Palaeoclimatol. Palaeoecol. 126, 101-108.

Lécuyer, C., Grandjean, P., O’Neil, J.R., Cappetta, H., Martineau, F., 1993. Therma excursions in the ocean at the Cretaceous-Tertiary boundary (northern Morocco): the $\delta^{18} \mathrm{O}$ record of phosphatic fish debris. Palaeogeogr. Palaeoclimatol. Palaeoecol. 105, 235-243.

Lee-Thorp, J.A., van der Merwe, N.J., Brain, C.K. 1994. Diet of Australopithecus robustus at Swartkrans from stable carbon isotopic analysis. J. Hum. Evol. 27, 361-372.

Leontiadis, J.L., Vergis, S., Christodoulou, Th., 1996. Isotope hydrology of areas in Eastern Macedonia and Thrace, Northern Greece. J. Hydrol. 182, 1-17.

Levinson, A.A., Luz, B., Kolodny, Y., 1987. Variations in oxygen isotopic compositions of human teeth and urinary stones. Appl. Geochem. 2, 367-371.

Longinelli, A., 1984. Oxygen isotopes in mammal bone phosphate: a new tool for paleohydrological and paleoclimatological research? Geochim. Cosmochim. Acta 48, 385-390.

Luz, B., Kolodny, Y., Horowitz, M., 1984. Fractionation of oxygen isotopes between mammalian bone-phosphate and environmental drinking water. Geochim. Cosmochim. Acta 48, 1689-1693.

Müller, W., Fricke, H., Halliday, A.N., McCulloch, M.T., Wartho, J.-A., 2003. Origin and migration of the Alpin Iceman. Science 302, 862-866.

OIPC: The Online Isotopes in Precipitation Calculator. Available from: http://www waterisotopes.org/, 2008.
O'Neil, J.R., Adami, L.H., Epstein, S., 1975. Revised value for the ${ }^{18} \mathrm{O}$ fractionation between $\mathrm{CO}_{2}$ and $\mathrm{H}_{2} \mathrm{O}$ at $25^{\circ} \mathrm{C}$. J. Res. US Geol. Surv. 3, 623-624.

O’Neil, J.R., Roe, J.L., Reinhard, E., Blake, R.E., 1994. A rapid and precise method of oxygen isotope analysis of biogenic phosphate. Isr. J. Earth Sci. 43, 203-212.

Patou-Mathis, M., 2006. Neanderthal. Une autre humanité. Perrin, Paris, pp. 342

Richards, M.P., Jacobi, R., Cook, J., Pettitt, P.B., Stringer, C.B., 2005. Isotope evidence for the intensive use of marine foods by Late Upper Paleolithic humans. J. Hum. Evol. 49, 390-394.

Richards, M.P., Pettitt, P.B., Trinkaus, E., Smith, F.H., Paunovic, M., Karavanic, I., 2000 Neanderthal diet at Vindija and Neanderthal predation: the evidence from stable isotopes. Proc. Nat. Acad. Sci. U.S.A. 97, 7663-7666.

Schmidt, H.-L., Werner, R.A., Roßmann, A., 2001. ${ }^{18} \mathrm{O}$ pattern and biosynthesis of natural plant products. Phytochemistry 58, 9-32.

Sokal, R.R., Rohlf, F.J., 1995. Biometry: The Principles and Practice of Statistics in Biological Research. W.H. Freeman and Co., New York, pp. 887

Sponheimer, M. Lee-Thorp, J., de Ruitter, D., Codron, D., Codron, J., Baugh, A.T. Thackeray, F., 2005. Hominids, sedges and termites: new carbon isotope data from the Sterkfontein valley and Kruger National Park. J. Hum. Evol. $48,301-312$.

Thiem, I., Lüpke, M., Seifert, H., 2004. Factors influencing the ${ }^{18} \mathrm{O} /{ }^{16} \mathrm{O}$ ratio in meat juices. Isot. Environ. Health Stud. 40, 191-197.

U.S. Department of Agriculture, Agricultural Research Service, 2005. USDA Nutrient Database for Standard Reference, Release 18. Nutrient Data Laboratory Home Page. Available from: http://www.ars.usda.gov/ba/bhnrc/ndl.

Van der Merwe, N.J., Thackeray, J.F., Lee-Thorp, J.A., Luyt, J., 2003. The carbon isotope ecology and diet of Australopithecus africanus at Sterkfontein, South Africa. J. Hum. Evol. 44, 581-597.

Vennemann, T.W., Fricke, H.C., Blake, R.E., O’Neil, J.R., Colman, A., 2002. Oxygen isotope analysis of phosphates: a comparison of techniques for analysis of $\mathrm{Ag}_{3} \mathrm{PO}_{4}$. Chem. Geol. 185, 321-336.

Von Grafenstein, U., Erlenkeuser, H., Müller, J., Trimborn, P., Alefs, J., 1996. A 200 year mid-European air temperature record preserved in lake sediments: an extension of the $\delta^{18} \mathrm{Op}$-air temperature relation in the past. Geochim. Cosmochim. Acta 60, 4025-4036.

Weiss, E., Kislev, M.E., Simchoni, O., Nadel, D., 2004. Small-grained wild grasses as staple food at the 23000 -year-old site of Ohalo II, Israel. Econ. Bot. 58, 125-134.

White, C.D., Longstaffe, F.J., Spence, M.W., Law, K.R., 2000. Teotihuacan state representation at Kaminaljuyú: evidence from oxygen isotopes. J. Anthropol. Res. 56, 535-558.

White, C.D., Price, T.D., Longstaffe, F.J., 2007. Residential histories of the human sacrifices at the moon pyramid, Teotihuacan. Ancient Mesoamerica 18, 159-172.

Wright, L.E., Schwarcz, H.P., 1998. Stable carbon and oxygen isotopes in human tooth enamel: identifying breastfeeding and weaning in prehistory. Am. J. Phys. Anthropol. 106, 1-18. 